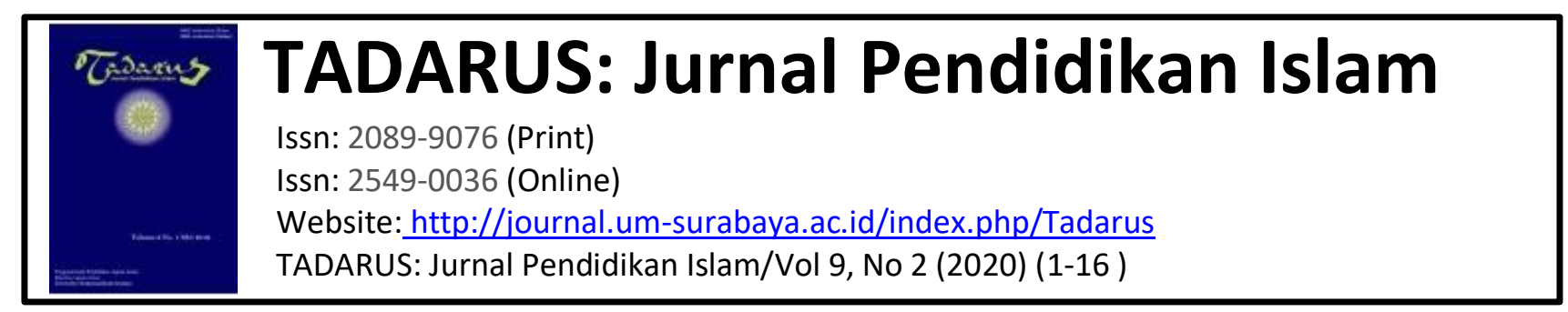

\title{
INTERNALISASI IDEOLOGI MUHAMMADIYAH MAHASISWA PROGRAM BEASISWA GURU MADIN STIT MUHAMMADIYAH BOJONEGORO
}

\author{
${ }^{1}$ Ahmad Syauqi Fuady \\ ${ }^{1}$ syauqi.asf68@gmail.com
}

\begin{abstract}
Abstrak
Penelitian ini dilakukan untuk mencari tahu sejauh mana internalisasi mahasiswa program Madin terhadap ideologi Muhammadiyah sebagai organisasi masyarakat Islam modern. Penelitian ini ingin mengetahui sejauh mana penerimaan mahasiswa Guru Madin terhadap nilai-nilai dasar, paham agama, visi-misi, ide-ide, dan nilai-nilai perjuangan dakwah Muhammadiyah. Penelitian ini merupakan penelitian kualitatif yang bersifat deskriptif dan eksploratif. Data penelitian ini diperoleh melalui angket kepada mahasiswa Semester 4 di kelas Program Beasiswa Guru Madin STIT Muhammadiyah Bojonegoro. Pendalaman data diperoleh melalui tanya jawab kepada mahasiswa. Sumber data lain diperoleh melalui wawancara dengan dosen pengampu mata kuliah, dokumentasi dan dokumen pembelajaran Kemuhammadiyahan. Hasil penelitian menunjukkan bahwa rata-rata sebanyak $22(81,9 \%)$ mahasiswa yang menjawab Setuju (S) dari total 18 item pernyataan dalam angket. Sedangkan rata-rata mahasiswa yang menjawab Ragu-ragu (R) sebanyak $4(14,8 \%)$, dan rata-rata sebanyak $1(3,3 \%)$ mahasiswa menjawab Tidak Setuju (TS). Data ini menunjukkan bahwa lebih dari $80 \%$ mahasiswa menginternalisasikan ideologi Muhammadiyah dalam wujud penerimaan atau persetujuan terhadap konsep-konsep, nilai-nilai, ideide, dan pandangan dasar Muhammadiyah. Sementara itu gagasan Muhammadiyah yang menerima ijtihad dengan tidak mengikuti salah satu mazhab hukum Islam, gagasan purifikasi dan dinamisasi Muhammadiyah, dan sikap netral Muhammadiyah dalam politik praktis dengan tidak dekat dengan partai politik tertentu memperoleh afirmasi Setuju (S) di angka 55-65\%.
\end{abstract}

Kata Kunci: Internalisa; Ideologi; Muhamamdiyah; Madin.

\section{Pendahuluan}

Pendidikan adalah amal usaha yang tidak bisa dipisahkan dari Muhammadiyah. Keduanya bagaikan dua sisi dari satu keping mata uang. Muhammadiyah identik dengan amal usaha pendidikan, dikarenakan amal usaha 
pendidikannya paling banyak di antara amal usaha bidang lain. ${ }^{1}$ Amal usaha Perguruan Tinggi Muhammadiyah dan Aisyiyah (PTMA) sejumlah 174 buah dengan rincian 18 akademi, 4 politeknik, 5 institut, 99 sekolah tinggi, dan 48 universitas. $^{2}$

Al-Islam dan Kemuhammadiyahan (AIK) adalah ciri khas institusi pendidikan Muhammadiyah di setiap jenjang pendidikan. Ketentuan khusus AIK di Perguruan Tinggi Muhammadiyah Aisyiyah (PTMA) disebutkan dalam Pedoman Pimpinan Pusat Muhammadiyah Nomor 02/PEDI/I.0/B/2012 tentang Perguruan Tinggi Muhammadiyah dalam Pasal 9 ayat (2), "Perguruan Tinggi Muhammadiyah wajib memiliki ciri khas kurikulum Al-Islam dan Kemuhammadiyahan yang diatur lebih lanjut dengan ketentuan Majelis Pendidikan Tinggi."3 Pelaksanaan pembelajaran AIK di PTMA diberikan empat fokus materi dari AIK I (Kemanusiaan dan Keimanan), AIK II (Ibadah, Akhlaq, dan Muamalah), AIK III (Kemuhammadiyahan), dan AIK IV (Islam dan Ilmu Pengetahuan).

Jumlah Sistem Kredit Semester (SKS) Al-Islam dan Kemuhammadiyahan bervariasi minimal 8 SKS dan maksimal 12 SKS. Pembelajaran AIK di program studi keagamaan dan non-keagamaan berbeda.Perbedaan ini dikarenakan di perguruan tinggi keagamaan, AIK I dengan fokus aqidah keimanan, AIK II dengan fokus ibadah, akhlaq, dan muamalah, AIK IV dengan materi Islam dan ilmu pengetahuan telah diberikan sebagai mata kuliah tersendiri. Sedangkan pengajaran AIK di perguruan tinggi keagamaan hanya memberikan materi AIK III yakni Kemuhammadiyahan. ${ }^{4}$

Mata kuliah Kemuhammadiyahan diberikan untuk memberikan pemahaman tentang Muhammadiyah dalam berbagai aspeknya dimulai dari sejarah

${ }^{1}$ Anonim, Data amal usaha pendidikan Muhammadiyah terdiri dari 4.623 TK/TPQ, 2.252 SD/MI, $\quad 1.111 \quad$ SMP/MTs, $1291 \quad$ SMA/SMK/MA dalam http://www.muhammadiyah.or.id/content-8-det-amal-usaha.html// diakses 27-September2019.

2 Anonim, "Daftar Perguruan Tinggi Muhammadiyah dan Aisyiyah", 23 November 2018 dalam http://www.suaramuhammadiyah.id/2018/11/23/daftar-perguruan-tinggimuhammadiyah-dan-aisyiyah-2018/ diakses 27-September-2019.

${ }^{3}$ Syamsul Arifin, "Rekonstruksi Al-Islam-Kemuhammadiyahan (AIK) Perguruan Tinggi Muhammadiyah Sebagai Praksis Pendidikan Nilai" dalam Edukasi: Jurnal Penelitian Pendidikan Agama dan Keagamaan, Volume 13, Nomor 2 Agustus (Jakarta: Puslitbang Kemenag, 2015), 203.

${ }^{4}$ Tim Pedoman Pendidikan Al-Islam dan Kemuhammadiyahan Majelis Pendidikan Tinggi PP Muhammadiyah, Buku Pedoman Pendidikan Al-Islam dan Kemuhammadiyahan Perguruan Tinggi Muhammadiyah (Yogyakarta: Majelis Pendidikan Tinggi Pimpinan Pusat Muhammadiyah, 2013), 23. 
Muhammadiyah, ideologi Muhammadiyah, dan nilai-nilai perjuangan Muhammadiyah dalam berbagai aspek. Pembelajaran Al-Islam dan Kemuhammadiyahan (AIK) di STIT Muhammadiyah Bojonegoro, sebagai Perguruan Tinggi Keagamaan Islam (PTKI), diwujudkan dengan mata kuliah Kemuhammadiyahan I (2 SKS) dan Kemuhammadiyahan II (2 SKS).

Sejak tahun 2007 STIT Muhammadiyah menyelenggarakan program khusus bagi peningkatan kualifikasi guru Madrasah Diniyah (Madin) untuk memperoleh gelar sarjana S-1. Program ini wujud kerja sama antara Pemprov Jawa Timur dengan perguruan tinggi swasta keagamaan di Jawa Timur. Program beasiswa ini dilandasi kenyataan bahwa di Provinsi Jawa Timur terdapat sekitar 7000 Madin yang berbasis pesantrendengan jumlah guru madin sekitar 80.000. Kenyataan lain, guru-guru Madin mayoritas belum sarjana. ${ }^{5}$ Sejak pertama kali program ini dijalankan tahun 2006-2018 sebanyak 11.967 guru madin yang tersebar di kabupaten-kabupaten di seluruh Jawa Timur telah menerima beasiswa, dan 7.595 telah lulus. ${ }^{6}$

Genealogi Madrasah Diniyah tidak bisa dilepaskan dari keberadaan pesantren tradisional (salafiyah). ${ }^{7}$ Secara umum, madrasah merupakan kelanjutan dari pesantren dalam merespons perkembangan zaman. Secara kelembagaan pendidikan, madrasah identik dan lekat dengan nilai-nilai relijiusitas. Hal ini berbeda dengan sekolah pada umumnya. Madrasah Diniyah merupakan lembaga pendidikan nonsekolah yang berorientasi keagamaan dan dilakukan secara klasikal. Keberadaan Madrasah Diniyah (madin) sejak tingkat awaliyah, wustho, dan ula lahir sebagai subsistem pesantren tetap akan menjadi bagian penting untuk mengajarkan agama (tafaqquh fiddiin). Hal ini sejalan dengan orientasi tafaqquh fiddiin selalu menjadi misi dan orientasi utama dalam sistem pendidikan pesantren meski pembaruan terjadi di beberapa aspek. ${ }^{8}$

Penelitian ini dilakukan untuk mencari tahu sejauh mana internalisasi mahasiswa program Madin, yang mayoritas berlatar belakang pesantren tradisional

\footnotetext{
${ }^{5}$ M. Nafiur Rofiq, "Eksistensi Kebijakan Pemerintah Provinsi Jawa Timur Terhadap Peningkatan Kualifikasi Akademik Guru Madrasah Diniyah di Jawa Timur" dalam Jurnal Falasifa, Volume 2, Nomor 1, Maret 2011, 54.

${ }^{6}$ Nuraini Faiq, "1015 Guru Madin Dapat Beasiswa Kuliah Gratis Dari Pemprov Jatim”, Kamis 18 Oktober 2018, dalam https://surabaya.tribunnews.com/2018/10/18/1015-guru-madindapat-beasiswa-kuliah-gratis-dari-pemprov-jatim diakses 27-September-2019.

${ }^{7}$ M. Nafiur Rofiq, "Eksistensi...”, 62

${ }^{8}$ Ahmad Syauqi Fuady, "Pembaharuan Sistem Pendidikan di Pesantren”, dalam Jurnal AlInsyiroh Vol 6, No 1, Maret 2020, 101-114. Doi: https://doi.org/10.35309/alinsyiroh.v6i1.3819
} 
(salafiyah), terhadap ideologi Muhammadiyah sebagai organisasi masyarakat Islam modern. Sejauh mana penerimaan mahasiswa Program Beasiswa Kualifikasi Guru Madin terhadap nilai-nilai luar yang berbeda dengan nilai-nilai yang dipeganginya, seperti nilai dasar, paham agama, visi-misi, ide-ide, dan nilai-nilai perjuangan dakwah Muhammadiyah.

\section{Metode Penelitian}

Penelitian ini merupakan penelitian kualitatif yang bersifat deskriptif dan eksploratif. Data penelitian ini diperoleh melalui angket kepada mahasiswa Semester 4 di kelas program madin STIT Muhammadiyah Bojonegoro. Pendalaman data diperoleh melalui tanya jawab kepada mahasiswa. Sumber data lain diperoleh melalui wawancara dengan dosen pengampu mata kuliah, dokumentasi dan dokumen pembelajaran Kemuhammadiyahan, pedoman AIK, dan jurnal-jurnal yang relevan. Sebanyak 28 mahasiswa dan dua dosen pengampu mata kuliah menjadi sumber data penelitian ini. Penelitian dilakukan selama bulan Maret-April 2020.

Langkah-langkah penelitian yang dilakuan: Pertama, menyusun instrumen penelitian. Kedua, menggali data dari obyek utama mahasiswa semester 3 Program Beasiswa Kualifikasi Guru Madin tahun akademik 2019/2020 dan dosen pengampu mata kuliah. Ketiga, mengumpulkan data dari sumber-sumber yang telah ditentukan. Keempat, analisis data yang diperoleh dengan beberapa langkah: a. Reduksi data dengan memilih data yang sesuai dengan tujuan penelitian, b. Penyajian data dengan mendeskripsikan hasil data penelitian secara naratif dan sistemtis agar mudah dipahami, dan c. Penarikan kesimpulan.

\section{Pembahasan Hasil Penelitian}

\section{Ideologi Muhammadiyah dan AIK}

Muhammadiyah didirikan oleh Ahmad Dahlan di Yogyakarta tanggal 18 November 1912 M/8 Zulhijah 1330 H. Penamaan Muhammadiyah untuk menisbahkan diri dengan ajaran Nabi Muhammad saw. Artinya pengikut Muhammadiyah adalah umat Nabi Muhammad saw, asasnya adalah ajaran yang 
dibawa Nabi Muhammad, dan berusaha melaksanakan ajaran Islam dalam kehidupan sehari-hari. ${ }^{9}$

Muhammadiyah memiliki seperangkat ideologi. Ideologi adalah sebagai seperangkat keyakinan dan paradigma pengetahuan yang menyeluruh dan sistematis yang memberikan landasan interpretasi untuk bertindak. Setiap ideologi idealnya mampu memadukan tiga unsur: Keyakinan berisi nilai normatif, pengetahuan berupa seperangkat kerangka memahami realitas, dan tindakan sebagai wujud konkrit keyakinan dan pengetahuan. ${ }^{10}$

Muhammadiyah mendefinisikan ideologi sebagai "keyakinan hidup yang mencakup pandangan hidup, tujuan hidup, dan ajaran serta yang digunakan untuk melaksanakan pandangan hidup dalam mencapai tujuan hidup." Ideologi tidak hanya berisi paham pemikiran, namun juga teori dan strategi mewujudkan paham tersebut dalam kehidupan. Sehingga ideologi Muhammadiyah adalah sistem keyakinan, citacita, dan perjuangan Muhammadiyah sebagai gerakan Islam dalam mewujudkan masyarakat Islam yang sebenar-benarnya. Ideologi Muhammadiyah mencakup a. Paham Islam atau paham agama dalam Muhammadiyah, b. Hakikat Muhammadiyah sebagai Gerakan Islam, dan c. Misi, fungsi, dan strategi perjuangan Muhammadiyah. ${ }^{11}$ Ideologi Muhammadiyah juga terdapat dalam konsep Kepribadian Muhammadiyah, Matan Keyakinan dan Cita-cita Hidup Muhammadiyah, dan Khittah Muhammmadiyah. ${ }^{12}$

Tujuan awal didirikannya Muhammadiyah dalam anggaran dasar: a. Menyebarkan pengajaran agama kanjeng Nabi Muhammad saw kepada penduduk Bumiputra di dalam residensi Yogyakarta, dan b. Memajukan hal agama kepada anggota-anggotanya. ${ }^{13}$ Dua kata kunci dalam anggaran dasar tersebut menunjukkan identitas Muhammadiyah: Menyebarkan artinya gerakan dakwah, dan memajukan berarti gerakan tajdid. ${ }^{14}$

\footnotetext{
${ }^{9}$ Haedar Nashir, Muhammadiyah Gerakan Pembaruan (Yogyakarta: Suara Muhammadiyah, cetakan pertama Maret 2010), 18-19.

${ }^{10}$ Yudi Latif, Revolusi Pancasila (Jakarta: Penerbit Mizan, 2015), 38

${ }^{11}$ Suara Muhammadiyah dan Majelis Pendidikan Kader PP Muhammadiyah, Manhaj Gerakan Muhammadiyah Ideologi, Khittah, dan Langkah (Yogyakarta: Suara Muhammadiyah, 2012), xvi.

${ }^{12}$ Suara Muhammadiyah, Manhaj Gerakan, xx-xxi.

${ }^{13}$ Ahmad Najib Burhani, Muhammadiyah Jawa (Yogyakarta: Suara Muhammadiyah, Februari 2016), 59-60.

${ }^{14}$ Haedar Nashir, Muhammadiyah, 23.
} 
Sebagai Gerakan Dakwah Muhammadiyah melakukan dakwah dengan kata lewat tabligh/pengajian (dakwah bil-lisan) juga dakwah dengan perbuatan lewat pendidikan, ekonomi, kesehatan, sosial, dan amal usaha lain (dakwah bil-hal). Model dakwah Muhammadiyah yang demikian ini sejalan dengan model pembaruan yang dilakukannya. Gerakan pembaruan yang dilakukan Muhammadiyah disebut sebagai gerakan pembaruan amaliah yang fokus utamanya adalah amal nyata dalam kehidupan. ${ }^{15}$ Ciri lain gerakan pembaruan atau tajdid keagamaan adalah mengedepankan nalar atau logika dalam teori dan memperbarui sistem pendidikan dalam praksis. ${ }^{16}$

Pendidikan identik dengan Muhammadiyah. Persyarikatan Muhammadiyah didirikan untuk menjaga keberlangsungan lembaga pendidikan yang didirikan. Bisa dikatakan pendidikan adalah sebab langsung kelahiran Muhammadiyah. ${ }^{17}$ Ahmad Dahlan melakukan modernisasi sistem pendidikan yang saat itu terpolarisasi antara sistem sekolah modern Barat dan pondok pesantren tradisional dengan mendirikan sekolah klasikal yang memadukan pelajaran umum dan agama.

Pendidikan Muhammadiyah merupakan pendidikan Islam modern yang mengintegrasikan antara agama dan kehidupan; antara iman dan kemajuan secara holistik; membentuk manusia beriman dan menguasai ilmu pengetahuan, teknologi modern, dan seni (IPTEKS) untuk menumbuhkan karakter sesuai nilai-nilai keislaman serta mendorong mobilitas sosial vertikal dengan penguasaan ilmu pengetahuan. $^{18}$

Pendidikan di Muhammadiyah memiliki mata ajar khusus dan sifatnya wajibyakni mata kuliah Al-Islam dan Kemuhammadiyahan (AIK). Keputusan Muktamar Muhammadiyah ke-46 tentang Program Muhammadiyah 2010-2015 mengamanatkan: "Mengembangkan model-model pendidikan Al-Islam dan Kemuhammadiyahan di seluruh jenjang pendidikan yang memberikan pencerahan paham Islam dan komitmen gerakan Muhammadiyah yang berkemajuan." 19 AIK memiliki misi ganda memberikan mahasiswa pendidikankeimanan dan keislaman (AIK I, II, dan IV ) serta mengenalkan Muhammadiyah (AIK III).

\footnotetext{
${ }^{15}$ Haedar Nashir, Muhammadiyah, 1-2.

${ }^{16}$ Ahmad Najib Burhani, Muhammadiyah Jawa, 61.

${ }^{17}$ M. Yusron Asrofie, Kyai Haji Ahmad Dahlan Pemikiran dan Kepemimpinannya (Yogyakarta: MPKSDI PP Muhammadiyah, 2005), 78.

${ }^{18}$ Syamsul Arifin, "Rekonstruksi...", 204-205.

${ }^{19}$ Tim Pedoman, Buku Pedoman, 11.
} 
Pengenalan ideologi Muhammadiyah dilakukan melalui AIK III (Kemuhammadiyahan). Standar kompetensi pembelajaran AIK III (Kemuhammadiyahan) adalah: a. Memahami sejarah Muhammadiyah, b. Memahami nilai-nilai ideologi Muhammadiyah, dan c. Memahami nilai perjuangan Muhammadiyah dalam berbagai aspek. ${ }^{20}$

\section{Madrasah Diniyah (Madin)}

Keberadaan madrasah sebagai mata rantai pendidikan Islam di Indonesia dapat dirunut hingga awal abad ke-20. Madrasah tidak bisa dipisahkan dari pondok pesantren tradisional (salafiyah). Karena sejatinya, madrasah adalah model pembaruan atau sintesis kreatif yang dilakukan pondok pesantren. Madrasah menjadi lembaga pendidikan Islam yang mengajarkan pengetahuan agama secara klasikal: ada ruangan, meja, kursi, dan kurikulum. Madrasah diniyah merupakan kelanjutan dari upaya pondok pesantren untuk mengajarkan pendidikan agama Islam. Peran penting Madrasah Diniyah dikuatkan dengan peraturan pemerintah dalam Peraturan Menteri Agama RI Nomor 13 tahun1964.

Tanggal 24 Maret 1975 Pemerintah mengeluarkan Surat Keputusan Bersama (SKB) Tiga Menteri. Dengan keputusan ini madrasah diniyah menjadi institusi formal dengan kurikulum $70 \%$ bermuatan umum dan $30 \%$ bermuatan agama. Denagn peraturan ini maka lulusan Madrasah Diniyah mendapat kesetaraan 'nasib' dengan memperoleh ijazah yang diakui sebagaimana lulusan sekolah umum pada umumnya. Akibat yang muncul dari keputusan ini Madrasah Diniyah bertransformasi menjadi Madrasah Ibtidaiyah, Madrasah Tsanawiyah, dan Madrasah Aliyah. $^{21}$ Kondisi ini mengakibatkan kedudukan Madrasah Diniyah sebagai pendidikan berciri khusus keagamaan Islam menjadi sekadar takmiliyah atau pelengkap pendidikan di sekolah atau madrasah. Kenyataan ini menjadikan Madrasah Diniyah disebut sebagai "Sekolah Sore" karena waktu pendidikannya sore setelah anak-anak selesai sekolah.

Legalitas Madrasah Diniyah sebagai satuan pendidikan keagamaan Islam diakui dalam UU Sistem Pendidikan Nasional nomor 20/2003 maupun peraturan pemerintah PP No 55 Tahun 2007 tentang Pendidikan Agama dan Keagamaan. Peraturan Pemerintah No 55 Tahun 2007 mengatur pendidikan diniyah menjadi

\footnotetext{
${ }^{20}$ Tim Pedoman, Buku Pedoman, 34.

${ }^{21}$ Nuriyatun Nizah, "Dinamika Madrasah Diniyah: Suatu Tinjauan Historis" dalam Jurnal Edukasia, Volume 11, No. 1, Februari 2016, 187-189.
} 
diniyah formal, nonformal, dan informal. Madrasah Diniyah nonformal dikenal dengan nama Madrasah Diniyah Takmiliyah (MDT) yang mengajarakan Al-Quran, Hadits, Fiqih, Bahasa Arab, dan materi-materi keislaman lainnya. ${ }^{22}$

Data dari Sekretariat Ditjen Pendidikan Islam Kementerian Agama RI tercatat ada lebih dari 73 ribu Madin, 4,9 juta santri, dan 392 ribu guru Madin di seluruh Indonesia. ${ }^{23}$ Potensi besar yang dimiliki oleh Madrasah Diniyah Takmiliyah (MDT) layak mendapat perhatian dari pemerintah, baik pemerintah pusat maupun daerah. Perhatian yang besar dari pemerintah diharapkan mampu meningkatkan kualitas Madrasah Diniyah Takmiliyah (MDT). Upaya peningkatan kualitas Madrasah Diniyah perlu dilakukan agar kualitas proses dan lulusan Madrasah Diniyah semakin baik dan bermutu. Persoalan mutu dan kualitas ini yang menjadi kritik dan penilaian masyarakat. $^{24}$ Banyak persoalan dihadapi oleh Madrasah Diniyah saat ini: kelembagaan dan kepemilikan, manajemen pengelolaan, kurikulum, sarana dan prasarana, biaya operasional, siswa, dan guru.

Persoalan kualitas guru Madin teramat penting. Dari total 392 ribu guru Madin hanya $19 \%$ guru yang memiliki kualifikasi strata satu atau sarjana. ${ }^{25}$ Karena umumnya guru Madrasah Diniyah lulusan madrasah aliyah dan juga lulusan pondok pesantren. Peningkatan kualitas guru Madin dengan minimal memiliki kualifikasi sarjana sebagai syarat sertifikasi perlu dilakukan.

\section{Internalisasi Nilai-nilai AIK}

Internalisasi menurut Kamus Besar Bahasa Indonesia bermakna pengahayatan; penghayatan terhadap suatu ajaran, doktrin, atau nilai sehingga merupakan keyakinan dan kesadaran akan kebenaran doktrin atau nilai yang diwujudkan dalam sikap dan perilaku; penerimaan ide atau nilai dari luar diri sebagai bagian dirinya;

\footnotetext{
${ }^{22}$ Moh. Rosyid, "Lintasan Sejarah Madrasah Diniyah Muawanatul Muslimin Sejak Era PraKolonial dengan Diberlakukannya Perda Kabupaten Kudus tentang Madin Takmiliyah" dalam Jurnal Elementary, Vol. 3, No., Januari-Juni 2015.

${ }^{23}$ Bagian Perencanaan dan Sistem Informasi Sekretariat Ditjen Pendidikan Islam Kementerian Agama Republik Indonesia dari laman daring http://pendis.kemenag.go.id/file/dokumen/bukusaku1102.pdf diakses 14 Oktober 2019.

${ }^{24}$ Muji Lestari, "Mayoritas Pendidikan Diniyah di Indonesia Dinilai Tak Bermutu", Sabtu 9 Februari 2019, dalam https://faktualnews.co/2019/02/09/mayoritas-pendidikan-diniyaah-diindonesia-dinilai-tak-bermutu/123044/amp/ diakses 14 Oktober 2019

${ }^{25}$ Amri Amrullah, "Mayoritas Guru Diniyah Takmiliyah Belum Disertifikasi", Jumat 22 November 2013, dalam https://republika.co.id/berita/mwnp3b/mayoritas-guru-diniyahtakmiliyah-belum-disertifikasi diakses 14 Oktober 2019.
} 
konsep superego yang dikembangkan dalam kepribadian. ${ }^{26}$ Definisi yang terakhir yang sesuai dengan maksud dalam penelitian ini.

Internalisasi, menurut Mulyasa, adalah upaya menghayati dan mendalami nilai agar tertanam dalam diri setiap manusia. Upaya ini dilakukan malalui proses pendidikan, pembimbingan, dan pembinaan. ${ }^{27}$ Sementara itu Mulyana menjelaskan internalisasi sebagai menyatunya nilai dalam diri seseorang, atau penyesuaian keyakinan, nilai, sikap, praktik, dan aturan-aturan baku pada diri seseorang. ${ }^{28}$ Soediharto menjelaskan internalisasi sebagai proses menjadikan nilai sebagai bagian dari diri seseorang. ${ }^{29}$ Dengan demikian internalisasi yang dimaksudkan dalam artikel ini adalah penerimaan mahasiswa atas suatu nilai yang ditanamkan, diajarkan, dididikkan, dan dibimbingkan sebagai bagian dari proses pendidikan. Penerimaan atas nilai itu akan menjadi pola pikir, ucapan, sikap, dan karakter. Nilai yang terinternalisasi akan menajdi perilaku yang tampak dalam kehidupan sehari-hari.

Internalisasi tampak sekali dekat dengan pendidikan, sejatinya pendidikan adalah penanaman agama, nilai, karakter, budaya, dan lainnya. Internalisasi ditunjukkan dengan merasuknya nilai karakter ke dalam diri seseorang sehingga nilai-nilai tersebut mendarah daging dalam dirinya, menjiwai pola pikir, sikap, dan perilakunya, serta membangun kesadaran diri untuk mengaplikasikan nilai-nilai tersebut. ${ }^{30}$ Nilai-nilai yang ada dalam pendidikan Muhamamdiyah adalah nilai-nilai yang dilandai oleh Al-Islam dan Kemuhamamdiyahan (AIK).

AIK adalah mata kuliah pendidikan nilai yang arahnya bukan sekadar pendidikan nilai secara an sich, namun harus mampu menciptakan sistem dan lingkungan yang memungkinkan nilai-nilai tersebut hidup. ${ }^{31}$ Pembelajaran AIK hendaknya dilakukan dengan menekankan pengalaman keberislaman dalam

${ }^{26}$ https://kbbi.kemdikbud.go.id/entri/internalisasi diakses 4 November 2020.

27 Muhammad Munif, "Strategi Internalisasi Nilai-nilai PAI dalam Membentuk Karakter Siswa", dalam Jurnal Edureligia, Vol. 01, No. 01, Tahun 2017, 1-12.

${ }^{28}$ Nuraini, "Internalisasi Nilai-nilai Pendidikan Agama Islam pada Kegiatan Ekstrakurikuler Rohaniah Islam dalam Membina Karakter Peserta Didik di SMA Negeri 1 Air Puth Kecamatan Air Putih Kabupaten Batu Bara," dalam Jurnal ANSIRU PAI, Vol. 3, No. 2, JuliDesember 2019, 49-61.

${ }_{29}$ Moch. Sya'roni Hasan, "Internalisasi Nilai Toleransi Beragama di Desa Jarak Kec. Wonosalam, Kab. Jombang", dalam Dar El-Ilmi: Jurnal Studi Keagamaan, Pendidikan, dan Humaniora, Vol. 6, No. 1, April 2019, 79-111.

${ }^{30}$ Titik Sunarti Widyaningsih, Zamroni, Darmiyati Zuchdi, "Internalisasi dan Aktualisasi Nilai-nilai Karakter pada Sisiwa SMP dalam Perspektif Fenomenologis (Studi Kasus di SMP 2 Bantul)", dalam Jurnal Pembangunan Pendidikan: Fondasi dan Aplikasi, Volume 2, Nomor 2, 2014, 181-195.

${ }^{31}$ Syamsul Arifin, "Rekonstruksi...", 220. 
kehidupan sehari-hari. Meski praktiknya aspek kognitif dari AIK lebih menonjol dibandingkan praktik berislam. Oleh karena itu pembaruan dalam model dan metode pembelajaran perlu dilakukan. ${ }^{32}$ Nilai-nilai AIK dalam aqidah, akhlak, dan toleransi, tanggung jawab berbangsa dan bernegara menjadi materi untuk menanamkan karakter dan sikap anti radikalisme mahasiswa. ${ }^{33}$

AIK menjadi jembatan menyampaikan nilai-nilai Islam sebagai agama rahmatan lil alamin di Perguruan Tinggi Muhammadiyah Kupang yang sebagian mahasiswanya nonmuslim. AIK tidak menyebabkan kemunduran kualitas hubungan Perguruan Tinggi Muhammadiyah Kupang dengan mahasiswa. ${ }^{34}$ Pembelajaran AIK untuk memberi bekal keimanan, keislaman, akhlaq, dan kemuhammadiyahan bagi mahasiswa. Namun metode penyampaian harus variatif dan tidak konvensional sehingga nilai-nilai AIK dapat diterapkan dalam keseharian. ${ }^{35}$

Keterlibatan mahasiswa dalam pembelajaran AIK melalui metode Student Centered Learning (SCL) dapat menumbuhkan kualitas pemahaman para mahasiswa dan komitmen mereka untuk mengimplementasikan ajaran Muhammadiyah dalam semua aspek kehidupan, sosial, profesional dan ritual. ${ }^{36}$ Ekspektasi mahasiswa terhadap pembelajaran AIK adalah dapat menambah pengetahuannya tentang agama, dapat mempraktikkan agama dalam kehidupan sehari-hari, serta mampu memperbaiki akhlaq. Kesan pembelajaran AIK yang kaku harus diubah sehingga menjadi pembelajaran yang santai dan tidak membosankan. ${ }^{37}$ Pembelajaran AIK merupakan salah satu sarana pendidikan karaker religius, moderat, cerdas dan berilmu dalam lingkup Perguruan Tinggi Muhammadiyah. ${ }^{38}$

\footnotetext{
${ }^{32}$ Sulaeman, "Pembinaan Keislaman Mahasiswa Berbasis Tutorial" dalam Jurnal Tarbawi, Volume 1, No 1, 43-44.

${ }^{33}$ Ahmadi dan Hamim Farhan, Peran Mata Kuliah Al-Islam dan Kemuhammadiyahan dalam Membentuk Karakter untuk Mencegah Radikalisme pada Mahasiswa Universitas Muhammadiyah Gresik (Universitas Muhammadiyah Gresik, 2016)

${ }^{34}$ Muhammad Thamrin, "Al-Islam dan Kemuhammadiyahan", 85.

${ }^{35}$ Faridi, "Persepsi Mahasiswa", 68-69.

${ }^{36}$ Andriyani, Abuddin Nata, dan Didin Saefuddin, "Implementasi Kurikulum Al-Islam dan Kemuhammadiyahan (AIK) Melalui Model Student Centered Learning (SCL) di Program Studi Pendidikan Dokter Fakultas Kedokteran dan Kesehatan Universitas Muhammadiyah Jakarta" dalam Jurnal Ta'dibuna, Vol. 3, No. 2, Oct 2014, 163-164

37 Mir'atun Nisa', Ekspektasi Mahasiswa Terhadap Mata Kuliah Al-Islam dan Kemuhammadiyahan" dalam Prosiding Seminar Nasional Al-Islam dan Kemuhammadiyahan, 50.

${ }^{38}$ Hairul Huda, "Membangun Karakter Islami Melalui Al Islam dan Kemuhammadiyahan [Studi Analisis Perpres Nomer 87 Tahun 2017 tentang Penguatan Pendidikan Karakter (PPK)]" dalam Jurnal Tarlim, Vol. 2, No. 1, Maret 2019, 69.
} 
Wawancara dengan dua dosen pengampu untuk memperoleh poin-poin materi yang diajarkan pada mata kuliah Kemuhammadiyahan I dan Kemuhammadiyahan II. Dokumentasi pembelajaran memperkuat hasil wawancara dengan dosen pengampu. Dari hasil wawancara dan dokumentasi diperoleh pokok-pokok materi pembahasan, yaitu: Sejarah Muhammadiyah, Paham Agama Muhammadiyah, Ideologi Muhammadiyah, Pedoman Hidup Islami Warga Muhammadiyah, MKCH Muhammadiyah, Khittah Perjuangan Muhammadiyah, Muqoddimah AD/ART Muhammadiyah, Kepribadian Muhammadiyah, AD/ART Muhammadiyah, dan Amal Usaha Muhammadiyah.

Sebanyak 28 mahasiswa semester 4 program beasiswa Madin diberi angket secara daring yang berisi 18 item pernyataan. Setiap peryataan berisi tiga pilihan jawaban: Setuju (S), Ragu-ragu (R), dan Tidak Setuju (TS). Namun hanya 27 mahasiswa yang mengembalikan angket dengan isian yang lengkap dan dapat dikaji lebih lanjut, satu mahasiswa tidak mengembalikan dan tidak bisa dihubungi lebih lanjut dikarenakan sedang sakit. Angket yang disebarkan untuk memperoleh gambaran penerimaan atau internalisasi mahasiswa terhadap ideologi, nilai-nilai, paham agama, visi-misi, amal usaha, dan ide perjuangan Muhammadiyah. Berikut ini hasil angket kepada mahasiswa:

Tabel 1. Rekapitulasi Hasil Angket Kepada Mahasiswa

\begin{tabular}{|c|l|c|c|c|}
\hline No & \multicolumn{1}{|c|}{ Pernyataan } & S (\%) & R (\%) & TS (\%) \\
\hline $\mathbf{1 .}$ & $\begin{array}{l}\text { Muhammadiyah merupakan organisasi yang didirikan } \\
\text { untuk memahami, mengikut, dan melaksanakan ajaran } \\
\text { agama Islam yang dicontohkan Nabi Muhamamd saw }\end{array}$ & $\begin{array}{c}25 \\
(92,6)\end{array}$ & $2(7,4)$ & 0 \\
\hline $\mathbf{2 .}$ & $\begin{array}{l}\text { Muhammadiyah adalah organisasi atau persyarikatan } \\
\text { modern yang berorientasi kemajuan dan pembaruan }\end{array}$ & $\begin{array}{c}24 \\
(88,9)\end{array}$ & $2(7,4)$ & $1(3,7)$ \\
\hline 3. & $\begin{array}{l}\text { Gagasan kemajuan dan pembaruan Muhammadiyah } \\
\text { diperoleh Ahmad Dahlan saat berhaji dan belajar di } \\
\text { Makkah dan Mesir }\end{array}$ & $\begin{array}{c}20 \\
(74,1)\end{array}$ & $4(14,8)$ & $3(11,1)$ \\
\hline 4. & $\begin{array}{l}\text { Muhammadiyah mendasarkan gerakannya kepada Alquran } \\
\text { dan Sunnah Nabi Muhammad saw. }\end{array}$ & $\begin{array}{c}25 \\
(92,6)\end{array}$ & $2(7,4)$ & 0 \\
\hline 5. & $\begin{array}{l}\text { Muhammadiyah berpegang pada prinsip bahwa pintu } \\
\text { ijtihad senantiasa terbuka dan tidak berpegang pada salah } \\
\text { satu mazhab }\end{array}$ & $\begin{array}{c}16 \\
(59,3)\end{array}$ & $8(29,6)$ & $3(11,1)$ \\
\hline $\mathbf{6 .}$ & $\begin{array}{l}\text { Muhammadiyah meyakini bahwa agama tidak hanya } \\
\text { mengenai persoalan aqidah, ibadah, dan akhlak. Namun } \\
\text { juga berkaitan dengan persoalan pendidikan, kesehatan, } \\
\text { sosial, ekonomi, politik. }\end{array}$ & $\begin{array}{c}26 \\
(96,3)\end{array}$ & $1(3,7)$ & 0 \\
\hline 7. & $\begin{array}{l}\text { Sebagai gerakan tajdid, dalam bidang agama } \\
\text { Muhammadiyah melakukan pemurnian (purifikasi), dan } \\
\text { melakukan pembaruan (modernisasi) dalam urusan } \\
\text { muammalah duniawiyah. }\end{array}$ & $17(63)$ & $7(25,9)$ & $3(11,1)$ \\
\hline 8. & $\begin{array}{l}\text { Muhammadiyah adalah gerakan Islam dan dakwah yang } \\
\text { berjuang untuk menegakkan ajaran agama Islam menuju }\end{array}$ & 24 & $3(11,1)$ & 0 \\
\hline
\end{tabular}




\begin{tabular}{|c|c|c|c|c|}
\hline & $\begin{array}{lllll}\begin{array}{l}\text { terbentuknya } \\
\text { benarnya }\end{array} & \text { masyarakat } & \text { yang utama/sebenar- }\end{array}$ & & & \\
\hline 9. & $\begin{array}{l}\text { Muhammadiyah dalam melaksanakan dakwah dan tajdid } \\
\text { menjalin komunikasi dan kerja sama dengan pihak mana } \\
\text { pun untuk mewujudkan Islam rahmat bagi semesta Alam }\end{array}$ & $\begin{array}{c}23 \\
(85,2)\end{array}$ & $3(11,1)$ & $1(3,7)$ \\
\hline 10. & $\begin{array}{l}\text { Dakwah yan dilakukan Muhammadiyah meliputi banyak } \\
\text { aspek baik dakwah bil-lisan (perkataan/tulisan) maupun } \\
\text { dakwah dalam amal perbuatan(amal usaha) }\end{array}$ & $\begin{array}{c}26 \\
(96,3)\end{array}$ & $1(3,7)$ & 0 \\
\hline 11. & $\begin{array}{l}\text { Muhammmadiyah melaksanakan dakwah dengan menyeru } \\
\text { dan mengajak secara penuh santun, damai, toleransi dan } \\
\text { menghindari penghakiman dan mengkafirkan. }\end{array}$ & $\begin{array}{c}23 \\
(85,2)\end{array}$ & $3(11,1)$ & $1(3,7)$ \\
\hline 12. & $\begin{array}{l}\text { Muhammadiyah mengedepankan prinsip-prinsip Islam } \\
\text { tengahan atau moderat. }\end{array}$ & $\begin{array}{c}20 \\
(74,1)\end{array}$ & $6(22,2)$ & $1(3,7)$ \\
\hline 13. & $\begin{array}{l}\text { Muhammadiyah terlibat aktif dalam perjuangan dan } \\
\text { memajukan masyarakat, negara, dan bangsa Indonesia. }\end{array}$ & $\begin{array}{c}24 \\
(88,9)\end{array}$ & $3(11,1)$ & 0 \\
\hline 14. & $\begin{array}{l}\text { Muhammadiyah mengakui Pancasila sebagai } \\
\text { kesepakatan dan mengajak seluruh bangsa untuk } \\
\text { menciptakan negara dan bangsa Indonesia adil makmur dan } \\
\text { diridhoi Allah Swt }\end{array}$ & $\begin{array}{c}25 \\
(92,6)\end{array}$ & $2(7,4)$ & 0 \\
\hline 15. & $\begin{array}{l}\text { Muhammadiyah menilai Negara Kesatuan Republik } \\
\text { Indonesia (NKRI) sebagai sebuah negara Darussalam dan } \\
\text { sebagai tempat pembuktian amal perbuatan untuk } \\
\text { menciptakan kemajuan }\end{array}$ & $\begin{array}{c}22 \\
(81,5)\end{array}$ & $5(18,5)$ & 0 \\
\hline 16. & $\begin{array}{l}\text { Muhammadiyah dalam mencapai tujuan organisasinya } \\
\text { salah satunya dengan menyelenggarakan berbagai amal } \\
\text { usaha seperti pendidikan, kesehatan, sosial, dan ekonomi. }\end{array}$ & $\begin{array}{c}26 \\
(96,3)\end{array}$ & $1(3,7)$ & 0 \\
\hline 17. & $\begin{array}{l}\text { Muhammadiyah tidak buta politik meski tidak berpolitik } \\
\text { praktis dengan tidak menyelenggarakan amal usaha dalam } \\
\text { bidang politik. }\end{array}$ & $\begin{array}{c}15 \\
(55,6)\end{array}$ & $\begin{array}{c}11 \\
(40,7)\end{array}$ & $1(3,7)$ \\
\hline 18. & $\begin{array}{l}\text { Muhammadiyah bukan partai politik dan tidak berpihak } \\
\text { kepada salah satu partai politik. }\end{array}$ & $17(63)$ & $8(29,6)$ & $2(7,4)$ \\
\hline
\end{tabular}

(Sumber: Hasil Olah Data Angket dari Peneliti)

Rekapitulasi hasil angket kemudian diolah dan didapat data rata-rata pilihan jawaban dari responden 27 mahasiswa sebagai berikut:

Tabel 2. Rata-rata dan Persentase Jawaban Mahasiswa

\begin{tabular}{|c|c|c|c|c|c|c|}
\hline \multirow{2}{*}{ No } & \multicolumn{3}{|c|}{ Total Jawaban } & \multicolumn{3}{c|}{ Persentase Jawaban } \\
\cline { 2 - 7 } & S & R & TS & S & R & TS \\
\hline 1. & 22,1 & 4 & 0,9 & 81,9 & 14,8 & 3,3 \\
\hline
\end{tabular}

(Sumber: Hasil Olah Data Angket dari Peneliti)

Tabel di atas menunjukkan bahwa rata-rata sebanyak $22(81,9 \%)$ mahasiswa yang menjawab Setuju (S) dari total 18 item pernyataan dalam angket. Sedangkan rata-rata mahasiswa yang menjawab Ragu-ragu (R) sebanyak 4 (14,8\%), dan ratarata sebanyak $1(3,3 \%)$ mahasiswa menjawab Tidak Setuju (TS). Data ini menunjukkan bahwa lebih dari $80 \%$ mahasiswa menginternalisasikan ideologi Muhammadiyah dalam wujud penerimaan atau persetujuan terhadap konsep-konsep, nilai-nilai, ide-ide, dan pandangan dasar Muhammadiyah. 
Akan tetapi ada beberapa item pernyataan dalam angket yang menarik untuk digali lebih jauh. Setidaknya ada empat item pernyataan dalam angket yang skor Setuju (S) berkisar antara antara 55-65\%, yakni item nomor 5, 7, 17, dan 18. Itemitem tersebut berkaitan dengan gagasan Muhammadiyah yang menerima ijtihad dengan tidak mengikuti salah satu mazhab hukum Islam, gagasan purifikasi dan dinamisasi Muhammadiyah, dan sikap netral Muhammadiyah dalam politik praktis.

\section{Simpulan}

Data-data yang dihasilakan dalam penelitian ini menunjukkan bahwa rata-rata sebanyak $22(81,9 \%)$ mahasiswa yang menjawab Setuju (S) dari total 18 item pernyataan dalam angket. Sedangkan rata-rata mahasiswa yang menjawab Raguragu (R) sebanyak 4 (14,8 \%), dan rata-rata sebanyak $1(3,3 \%)$ mahasiswa menjawab Tidak Setuju (TS). Data ini menunjukkan bahwa lebih dari $80 \%$ mahasiswa menginternalisasikan ideologi Muhammadiyah dalam wujud penerimaan atau persetujuan terhadap konsep-konsep, nilai-nilai, ide-ide, dan pandangan dasar Muhammadiyah. Akan tetapi ada beberapa item pernyataan dalam angket yang menarik untuk digali lebih jauh. Setidaknya ada empat item pernyataan dalam angket yang skor Setuju (S) berkisar antara antara 55-65\%, yakni item nomor 5, 7, 17, dan 18. Item-item tersebut berkaitan dengan gagasan Muhammadiyah yang menerima ijtihad dengan tidak mengikuti salah satu mazhab hukum Islam, gagasan purifikasi dan dinamisasi Muhammadiyah, dan sikap netral Muhammadiyah dalam politik praktis.

\section{Referensi}

Ahmadi dan Hamim Farhan. 2016. Peran Mata Kuliah Al-Islam dan Kemuhammadiyahan dalam Membentuk Karakter untuk Mencegah Radikalisme pada Mahasiswa Universitas Muhammadiyah Gresik (Universitas Muhammadiyah Gresik).

Amrullah, Amri. 2019. "Mayoritas Guru Diniyah Takmiliyah Belum Disertifikasi”, Jumat 22 November 2013 dalam https://republika.co.id/berita/mwnp3b/mayoritas-guru-diniyah-takmiliyahbelum-disertifikasi diakses 14 Oktober 2019.

Andriyani, Abuddin Nata, dan Didin Saefuddin. 2014. "Implementasi Kurikulum Al-Islam dan Kemuhammadiyahan (AIK) Melalui Model Student Centered Learning (SCL) di Program Studi Pendidikan Dokter Fakultas Kedokteran dan 
Kesehatan Universitas Muhammadiyah Jakarta" dalam Jurnal Ta'dibuna, Vol. 3, No. 2, Oct 2014.

Anonim. 2019. Data amal usaha pendidikan Muhammadiyah terdiri dari 4.623 TK/TPQ, 2.252 SD/MI, 1.111 SMP/MTs, 1291 SMA/SMK/MA dalam http://www.muhammadiyah.or.id/content-8-det-amal-usaha.html/diakses 27September-2019.

Anonim. 2019. "Daftar Perguruan Tinggi Muhammadiyah dan Aisyiyah", 23 November 2018 dalam http://www.suaramuhammadiyah.id/2018/11/23/daftar-perguruan-tinggimuhammadiyah-dan-aisyiyah-2018/ diakses 27-September-2019.

Arifin, Syamsul. 2015. "Rekonstruksi Al-Islam-Kemuhammadiyahan (AIK) Perguruan Tinggi Muhammadiyah Sebagai Praksis Pendidikan Nilai” dalam Edukasi: Jurnal Penelitian Pendidikan Agama dan Keagamaan, Volume 13, Nomor 2 Agustus (Jakarta: Puslitbang Kemenag).

Asrofie, M. Yusron. 2005. Kyai Haji Ahmad Dahlan Pemikiran dan Kepemimpinannya (Yogyakarta: MPKSDI PP Muhammadiyah).

Bagian Perencanaan dan Sistem Informasi Sekretariat Ditjen Pendidikan Islam Kementerian Agama Republik Indonesia dari laman daring http://pendis.kemenag.go.id/file/dokumen/bukusaku1102.pdf diakses 14 Oktober 2019.

Burhani, Ahmad Najib. 2016. Muhammadiyah Jawa (Yogyakarta: Suara Muhammadiyah).

Faiq, Nuraini. 2019. “1015 Guru Madin Dapat Beasiswa Kuliah Gratis Dari Pemprov Jatim" Kamis 18 Oktober 2018 dalam https://surabaya.tribunnews.com/2018/10/18/1015-guru-madin-dapatbeasiswa-kuliah-gratis-dari-pemprov-jatim diakses 27-September-2019.

Faridi. 2010. "Persepsi Mahasiswa Terhadap Mata Kuliah Al Islam dan Kemuhammadiyahan (AIK): Internalisasi Nilai-nilai AIK bagi Mahasiswa" dalam Jurnal Progresiva, Volume 4, Nomor 1, Agustus 2010.

Fuady, Ahmad Syauqi. 2020. "Pembaharuan Sistem Pendidikan di Pesantren", dalam Jurnal Al-Insyiroh Vol 6, No 1, Maret 2020. Doi: https://doi.org/10.35309/alinsyiroh.v6i1.3819

Hasan, Moch. Sya'roni. 2019. "Internalisasi Nilai Toleransi Beragama di Desa Jarak Kec. Wonosalam, Kab. Jombang", dalam Dar El-Ilmi: Jurnal Studi Keagamaan, Pendidikan, dan Humaniora, Vol. 6, No. 1, April 2019.

Huda, Hairul. 2019. "Membangun Karakter Islami Melalui Al Islam dan Kemuhammadiyahan [StudiAnalisis Perpres Nomer 87 Tahun 2017 tentang Penguatan Pendidikan Karakter(PPK)]" dalam Jurnal Tarlim, Vol. 2, No. 1, Maret 2019. 
Kamus Besar Bahasa Indonesia (KBBI) daring dalam https://kbbi.kemdikbud.go.id/entri/internalisasi/diakses tangga 8 Oktober 2019.

Latif, Yudi. 2015. Revolusi Pancasila (Jakarta: Penerbit Mizan).

Lestari, Muji. 2019. "Mayoritas Pendidikan Diniyah di Indonesia Dinilai Tak Bermutu" Sabtu 9 Februari 2019dalam https://faktualnews.co/2019/02/09/mayoritas-pendidikan-diniyaah-diindonesia-dinilai-tak-bermutu/123044/amp/ diakses 14 Oktober 2019

Munif, Muhammad. 2017. "Strategi Internalisasi Nilai-nilai PAI dalam Membentuk Karakter Siswa", dalam Jurnal Edureligia, Vol. 01, No. 01, Tahun 2017.

Nashir, Haedar. 2010. Muhammadiyah Gerakan Pembaruan (Yogyakarta: Suara Muhammadiyah, cetakan pertama Maret 2010).

Nisa', Mir'atun. Ekspektasi Mahasiswa Terhadap Mata Kuliah Al-Islam dan Kemuhamamdiyahan" dalam Prosiding Seminar Nasional Al-Islam dan Kemuhammadiyahan.

Nizah, Nuriyatun. 2016. "Dinamika Madrasah Diniyah: Suatu Tinjauan Historis" dalam Jurnal Edukasia, Volume 11, No. 1, Februari 2016.

Nuraini. 2019. "Internalisasi Nilai-nilai Pendidikan Agama Islam pada Kegiatan Ekstrakurikuler Rohaniah Islam dalam Membina Karakter Peserta Didik di SMA Negeri 1 Air Putih Kecamatan Air Putih Kabupaten Batu Bara," dalam Jurnal ANSIRU PAI, Vol. 3, No. 2, Juli-Desember 2019.

Rofiq, M. Nafiur. 2011. "Eksistensi Kebijakan Pemerintah Provinsi Jawa Timur Terhadap Peningkatan Kualifikasi Akademik Guru Madrasah Diniyah di Jawa Timur" dalam Jurnal Falasifa, Volume 2, Nomor 1, Maret 2011.

Rosyid, Moh. 2015. "Lintasan Sejarah Madrasah Diniyah Muawanatul Muslimin Sejak Era Pra-Kolonial dengan Diberlakukannya Perda Kabupaten Kudus tentang Madin Takmiliyah" dalam Jurnal Elementary, Vol. 3, No.1, JanuariJuni 2015.

Suara Muhammadiyah dan Majelis Pendidikan Kader PP Muhammadiyah. 2012. Manhaj Gerakan Muhammadiyah Ideologi, Khittah, dan Langkah (Yogyakarta: Suara Muhammadiyah, 2012).

Sulaeman. "Pembinaan Keislaman Mahasiswa Berbasis Tutorial" dalam Jurnal Tarbawi, Volume 1, No 1.

Thamrin, Muhammad. 2019. "Al-Islam dan Kemuhammadiyahan (AIK) Pilar Dakwah Islam Rahmatan Lil Alamin (Studi Pada Perguruan Tinggi Muhammadiyah NTT" dalam Jurnal Ta'lim:Jurnal Studi Pendidikan Islam, Volume 2, Nomor 1, Januari 2019. 
Tim Pedoman Pendidikan Al-Islam dan Kemuhammadiyahan Majelis Pendidikan Tinggi PP Muhammadiyah. 2013. Buku Pedoman Pendidikan Al-Islam dan Kemuhammadiyahan Perguruan Tinggi Muhamamdiyah (Yogyakarta: Majelis Pendidikan Tinggi Pimpinan Pusat Muhammadiyah).

Widyaningsih, Titik Sunarti, Zamroni, Darmiyati Zuchdi. 2014. "Internalisasi dan Aktualisasi Nilai-nilai Karakter pada Sisiwa SMP dalam Perspektif Fenomenologis (Studi Kasus di SMP 2 Bantul)", dalam Jurnal Pembangunan Pendidikan: Fondasi dan Aplikasi, Volume 2, Nomor 2, 2014.

https://kbbi.kemdikbud.go.id/entri/internalisasi diakses 4 November 2020. 